Volume I Tahun 2021 November 2021
E-ISSN: 2808-5361

http://e-journal.fkmumj.ac.id/
Proceeding The First Muhammadiyah

Internasional- Public Health and Medicine Conference

\title{
RISK FACTOR FOR CHRONIC KIDNEY DISEASE IN INTERNIST POLYCLINIC PATIENT AT RUMAH SEHAT TERPADU DOMPET DHUAFA HOSPITAL IN 2021
}

\author{
${ }^{1}$ Dessy Marlinda Cahaya, ${ }^{2}$ Munaya Fauziah \\ ${ }^{1,2}$ Faculty of Public Health, Muhammadiyah University of Jakarta \\ Jl. K.H. Ahmad Dahlan, Cireundeu, Ciputat, Kota Tangerang Selatan, Banten, 15419 \\ Email: dessymc19@gmail.com
}

\begin{abstract}
Based on the data reports of Riset Kesehatan Dasar, the national prevalence of CKD in Indonesia is $0.38 \%$. The province of West Java is in the 8th rank of 34 other provinces, its prevalence is $0.48 \%$. The number of new cases of CKD at the Rumah Sehat Terpadu Dompet Dhuafa Hospital in 2020 increased from 47 people to 51 people. The object of this study is to identify the risk factors that can affect the incidence of CRF in the Rumah Sehat Terpadu Dompet Dhuafa Hospital, the Year 2021. Case-control design with 91 respondents as the control group and 91 respondents as the case group, the source of the data come from the medical records of RST DD Hospital. The sampling technique used is simple random sampling. The data analysis technique used is the chi-square test with $=0.05$. The influence of a history of diabetes mellitus ( $p$-value $=0.002 ;$ OR $: 2.810 ; 95 \% C I: 1.493$ - 5.287), history of hypertension ( $p$-value $=0.005 ;$ OR $: 2.796 ; 95 \% C I: 1.407-5.557$ ), history of obstructive nephropathy (p-value $=0.018 ;$ OR: 0.205; 95\%CI: $0.056-0.744$ ) against CKD. The risk factors that influence the incidence of CKD in the Rumah Sehat Terpadu Dompet Dhuafa Hospital are a history of diabetes Mellitus, hypertension, and obstructive nephropathy. The community must implement the Pola Hidup Bersih dan Sehat as their lifestyle. Health workers need to give an education on health to the community, especially for at-risk populations.
\end{abstract}

Keywords: Diabetes Mellitus, Hypertension, CKD, Obstructive Nephropathy 
E-ISSN: 2808-5361 http://e-journal.fkmumj.ac.id/

\section{Proceeding The First Muhammadiyah \\ Internasional- Public Health and Medicine Conference}

\section{INTRODUCTION}

Based on data from the Riset Kesehatan Dasar (RISKESDAS) 2018 it was noted that the prevalence of chronic kidney failure based on a doctor's diagnosis in the population aged 15 years was $0.38 \%$. The ten provinces with the highest prevalence are North Kalimantan $(0.64 \%)$, North Maluku (0.56\%), North Sulawesi (0.53\%), Central Sulawesi (0.52\%), Gorontalo (0.52\%), West Nusa Tenggara (0.52\%), Aceh (0.49\%), West Java (0.48\%), DKI Jakarta (0.45\%), and Bali $(0.44 \%)$. Meanwhile, the ten provinces with the lowest prevalence were West Sulawesi $(0.18 \%)$, Banten (0.25\%), Riau (0.26\%), South Sumatra (0.27\%), East Java (0.29\%), Bangka Belitung $(0.29 \%)$, Central Kalimantan $(0.31 \%)$, South Kalimantan (0.32\%), Kepulauan Riau (0.32\%), and Jambi $(0.32 \%)$. The Province of West Java is the province with the $8^{\text {th }}$ highest prevalence of 34 other provinces in Indonesia. ${ }^{1}$

Chronic kidney failure is defined as kidney failure in carrying out its function to maintain metabolism, and also balancing of fluid and electrolytes due to progressive destruction of kidney structures. $^{2}$

Chronic kidney failure is characterized by kidney damage or a decrease in the Glomerular Filtration Rate (GFR) to $<60 \mathrm{~mL} / \mathrm{min} / 1.73 \mathrm{~m} 2$ for 3 months or more. The decline in kidney function occurs gradually and is generally asymptomatic in the early stages. Decreased kidney function is characterized by a decrease in the GFR value as much as $25 \%$ of the normal value. The early stages usually do not cause symptoms, but blood urea and creatinine values have increased. ${ }^{3}$

Based on disease report data in the outpatient of the Rumah Sehat Terpadu Dompet Dhuafa Hospital in 2020, chronic kidney failure is one of the diseases that is included in the ten most diseases at the Rumah Sehat Terpadu Dompet Dhuafa Hospital Hospital with the number of new cases increasing from 47 people in 2019 to 51 people in 2020. The author has not found any research on risk factors that cause chronic kidney failure in Internist Polyclinic patients at the Rumah Sehat Terpadu Dompet Dhuafa Hospital. Therefore, the authors feel the need to conduct research related to the risk factors for chronic kidney failure in Internist Polyclinic patients at the Muhammadiyah and Rumah Sehat Terpadu Dompet Dhuafa Hospital.

\section{METHODS}

This study uses a quantitative approach with a case-control research design. The population of this study was all patients who received treatment at the Internist Polyclinic of the Rumah Sehat Terpadu Dompet Dhuafa Hospital in January-March 2021. The sample in this 
study amounted to 182 people consisting of 91 people as a case group and 91 people as a control group. This research is secondary data research using a simple random sampling technique. The data collection technique carried out in this study was by looking at the medical record data as the data source and then documented using a checklist form. This research has passed the ethical review at the University of Muhammadiyah and Rumah Sakit Terpadu Dompet Dhuafa Hospital.

\section{RESULT}

Table 1. Univariate Analysis Results

\begin{tabular}{|c|c|c|c|}
\hline Variable & Category & $\mathbf{N}$ & $\%$ \\
\hline Chronic Kidney & Case & 91 & 50.0 \\
Failure & Control & 91 & 50.0 \\
\hline Age & $>45$ years & 135 & 74.2 \\
& $\geq 45$ Years & 47 & 25.8 \\
\hline Sex & Male & 74 & 40.7 \\
& Female & 108 & 59.3 \\
\hline Diabetes Mellitus & Yes & 65 & 35.7 \\
& No & 117 & 64.3 \\
\hline Hypertension & Yes & 50 & 27.5 \\
& No & 132 & 72.5 \\
\hline Kidney Polycystic & Yes & 12 & 6.6 \\
& No & 170 & 93.4 \\
\hline Obstructive & Yes & 16 & 8.8 \\
Nephropathy & No & 166 & 91.2 \\
\hline
\end{tabular}

Based on the research data in the table above, it can be concluded that there are 91 people $(50.0 \%)$ who suffer from chronic kidney failure (cases) and there are 91 people $(50.0 \%)$ who do not suffer from chronic kidney failure (controls). From 182 respondents found that there were 135 people $(74.2 \%)$ aged $>45$ years and 47 people $(25.8 \%) \leq 45$ years. There are 74 people $(40,7 \%)$ are male and 108 people $(59,3 \%)$ are female. Then from the history of chronic diseases that have been suffered before suffering from chronic kidney failure are as follows, 65 people $(35,7 \%)$ have a history of diabetes mellitus, 50 respondents $(27,5 \%)$ have a history of hypertension, 12 people $(6,6 \%)$ had a history of polycystic kidney disease, and $16(8,8 \%)$ had a history of obstructive nephropathy.

Table 2. Effect of Age, Sex, History of Diabetes Mellitus, Hypertension, Kidney Polycystic, and Obstructive Nephropathy on Chronic Kidney Failure

\begin{tabular}{|l|c|c|c|}
\hline \multicolumn{1}{|c|}{ Variable } & P-Value & OR & CI95\% \\
\hline $\begin{array}{l}\text { Age }>45 \text { years } \\
\geq 45 \text { years }\end{array}$ & 1,000 & 0,944 & $0,486-1,834$ \\
\hline
\end{tabular}




\begin{tabular}{|l|c|c|c|}
\hline $\begin{array}{l}\text { Sex } \\
\text { Male } \\
\text { Female }\end{array}$ & 0,451 & 1,315 & $0,727-2,379$ \\
\hline $\begin{array}{l}\text { Diabetes Mellitus } \\
\text { Yes } \\
\text { No }\end{array}$ & 0,002 & 2,810 & $1,493-5,287$ \\
\hline $\begin{array}{l}\text { Hypertension } \\
\text { Yes } \\
\text { No }\end{array}$ & 0,005 & 2,796 & $1,407-5,557$ \\
\hline $\begin{array}{l}\text { Kidney Polycystic } \\
\text { Yes } \\
\text { No }\end{array}$ & 0,135 & 3,220 & $0,842-12,306$ \\
\hline $\begin{array}{l}\text { Obstructive Nephropathy } \\
\text { Yes } \\
\text { No }\end{array}$ & 0,018 & 0,205 & $0,056-0,744$ \\
\hline
\end{tabular}

The results of the analysis of the influence of age with the incidence of chronic kidney failure in patients at the Internist Polyclinic of RST DD Hospital found that from the group of patients suffering from chronic kidney failure there were 67 people $(73.6 \%)$ aged $>45$ years, while those aged $\leq 45$ years there were 24 people $(26.4 \%)$. From the results of statistical tests obtained p-value > 0.05 (1.000).

The result of the analysis of the influence of sex on the incidence of chronic kidney failure in patients at the Internist Polyclinic of RST DD Hospital, it was found that from the group of patients suffering from chronic kidney failure there were 40 people (44.0\%) male, while the male there is 51 female (56.0\%). From the results $\mathrm{f}$ statistical tests obtained p-value > 0.05 (0.451).

The results of the analysis of the influence of a history of diabetes mellitus with the incidence of chronic kidney failure in patients at the Internist Polyclinic of RST DD Hospital, it was found that from the group of patients suffering from chronic kidney failure there were 43 people $(47.3 \%)$ who had a history of diabetes mellitus, while those who did not have a history of diabetes mellitus there were as many as 48 people (52.7\%). From the results of statistical tests obtained p-value $<0.05$, which is 0.002 and OR is 2.810 .

The results of the analysis of the influence of a history of hypertension with the incidence of chronic kidney failure in patients at the Internist Polyclinic of RS DD RST obtained that from the group of patients suffering from chronic kidney failure there were 34 people $(37.4 \%)$ had a history of hypertension, while those who did not have a history of hypertension were as many as 57 people (62.6\%). From the results of statistical tests obtained pvalue $<0.05$, which is 0.005 and $\mathrm{OR}$ is 2.796 .

The results of the analysis of the influence of a history of polycystic kidney disease with the incidence of chronic kidney failure in patients at the Internist Polyclinic of RST DD 
Hospital, it was found that from the group of patients suffering from chronic kidney failure there were as many as 9 people (9.9\%) who had a history of polycystic kidney disease, while there were 82 people $(90,1 \%)$ who did not have a history of polycystic kidney disease. From the results of statistical tests obtained p-value $>0.05(0.135)$.

The results of the analysis of the influence of a history of obstructive nephropathy with the incidence of chronic kidney failure in patients at the Internist Polyclinic of RST DD Hospital found that from the group of patients suffering from chronic kidney failure there were 3 people (3.3\%) who had a history of obstructive nephropathy, while there were 88 people (96.7\%) who did not have a history of obstructive nephropathy. From the results of statistical tests obtained p-value $<0.05$, which is 0.018 and $\mathrm{OR}$ is 0.205 .

\section{DISCUSSION}

Based on the results of the bivariate analysis, the study showed that age did not have a statistically significant effect on the incidence of chronic kidney failure in patients at the Internist Polyclinic of RST DD Hospital with a p-value of 1.000. This is not in line with research conducted by other researchers. Pranandari and Supadmi (2015) in their research stated that there was a statistically significant relationship between age and the incidence of chronic kidney failure. Delima, et al (2017) stated that the increasing age, the greater the risk of experiencing chronic kidney failure.

In the discussion in his research, Langi, et al (2019) also mentioned that naturally as a person ages, his body cells will also weaken. At the age of 40 years, the number of functioning nephrons will decrease by $10 \%$ every 10 years.

A similar theory was also explained by Hartono in a study conducted by Harahap (2018), that after the age of 40 the kidney function will decrease, and when it reaches the age of 90 it is predicted that kidney function will decrease by $50 \%{ }^{4}$

Based on the bivariate analysis, the study showed that sex did not have a statistically significant effect on the incidence of chronic kidney failure in patients at the internist polyclinic of RST DD Hospital with a p-value of 0.451 . The results of this study are in line with research conducted by Logani, et al (2017) which states that sex is not the main risk factor for chronic kidney failure because it is also influenced by age, lifestyle, and other factors.

However, the results of this study are not in line with the results of research conducted by Arifa, et al (2017) which states that male respondents have a 1.783 times greater risk of suffering from chronic kidney failure. In addition, another study also stated that there was a significant effect between sex and the incidence of chronic kidney failure was a study conducted 
by Pranandari and Supadmi (2015), in their research results they stated that clinically males had a 2 times greater risk to suffer from chronic kidney disease when compared with females.

Most diseases can affect everyone, both male and female, but several things make one of them more at risk of a disease, such as work, life habits, genetics, and physiological conditions. ${ }^{5}$

The author argues that scientifically sex does not have a significant influence on the incidence of chronic kidney failure. In some studies, the number of patients with chronic kidney failure is more male than female patients, this may be influenced by male lifestyles which tend to be more at risk for chronic kidney failure, for example, consumption energy supplement drinks, alcoholic beverages, soft drinks, then lack of discipline in carrying out the treatment of chronic diseases suffered previously.

Based on the bivariate analysis, the study showed that there was a statistically significant effect between a history of diabetes mellitus and the incidence of chronic kidney failure in patients at the Internist Polyclinic of RST DD Hospital with a p-value of 0.002 and an OR of 2.810, meaning that people with a history of diabetes mellitus had a risk of 2.810 times to suffer from chronic kidney failure when compared with people without a history of diabetes mellitus.

This is in line with research conducted by Adhiatma, et al (2014) which states that patients with diabetes mellitus have a 5.333 times greater risk of suffering from chronic kidney failure when compared to patients who do not have a history of diabetes mellitus. Another study conducted by Pongsibidang (2016) also stated the same thing that patients with a history of diabetes mellitus have a greater risk of suffering from chronic kidney failure when compared to patients who do not have a history of diabetes mellitus.

Patients who have a history of diabetes mellitus are 20 times more likely to experience kidney damage. Patients who have suffered from diabetes mellitus for 10-15 years usually begin to experience microalbuminuria (the release of protein or albumin in the urine in the amount of $30-300 \mathrm{mg}$ in 24 hours of urine production), then later will cause macroalbuminuria. ${ }^{6}$

The presence of protein in the urine without being accompanied by other causes other than diabetes mellitus is usually known as diabetic nephropathy. End-stage renal failure is characterized by the presence of albumin in the urine with a concentration of $>300 \mathrm{mg} / \mathrm{L}$. The pathological feature of diabetic nephropathy is a thickening of the basement membrane and diffuse glomerulosclerosis. 7

Uncontrolled blood sugar and blood pressure can lead to more rapid kidney damage. To prevent kidney damage, it is necessary to do several things, in addition to strict control of blood 
sugar levels, other efforts are to go on a diet, control blood pressure, and also consume other supporting drugs that can prevent kidney damage by doctor's recommendations. ${ }^{6}$

Other factors that also influence the incidence of diabetic nephropathy are social factors which include social environment, education, food and beverage consumption habits, and physical activity. Poor social factors have been shown to increase the progression of kidney damage. ${ }^{8}$

The authors argue that people who have a history of diabetes mellitus have a very large risk of developing complications of chronic renal failure, considering that naturally, high sugar levels can damage podocyte cells located in the glomerulus. When podocyte cells are damaged, the glomerulus will also experience damage or a decrease in function. However, we can make efforts to slow the decline in kidney function so that the quality of life of people with diabetes mellitus can be better and more productive.

Based on the results of the study, there was a statistically significant effect between a history of hypertension and the incidence of chronic kidney failure in patients at the Internist Polyclinic of RST DD Hospital with a p-value of 0.005 and an OR of 2.796, meaning that people with a history of hypertension had a risk of 2.796 times for suffering from chronic kidney failure when compared with people without a history of hypertension.

This is in line with research conducted by Pralisa, et al (2020) which states that patients with hypertension have a 3.2 times greater risk of chronic kidney failure than those without hypertension. The same thing was stated by Adhiatma, et al (2014) in their research which states that patients suffering from hypertension have a 5.6 times risk of experiencing kidney failure when compared to patients who do not suffer from hypertension.

High blood pressure will cause damage to the blood vessels in the kidneys and then kidney function will decrease until it eventually becomes kidney failure. Kidney damage occurs gradually, so The longer you suffer from hypertension, the higher the risk of developing kidney failure. ${ }^{9}$

Hypertension can affect kidney function and vice versa. In addition to being a risk factor for chronic kidney failure, hypertension is also a condition that occurs in patients who have chronic kidney failure. Control of blood pressure and prevention of proteinuria in patients with hypertension can be done as an effort to slow down the decline in kidney function. ${ }^{10}$

The longer a person suffers from hypertension, the more at risk for complications in the form of a decrease or dysfunction in several organs of the body. The organs of the body that are most often damaged are the brain, eyes, heart, arteries, and kidneys. ${ }^{11}$ 
The author argues that hypertension and chronic kidney failure have an interrelated relationship. People who have a history of hypertension have a very large risk of developing complications of chronic kidney failure, considering that naturally, high blood pressure can damage blood vessels, including blood vessels located in the kidneys.

Based on the results of the study, it was shown that a history of polycystic kidney disease did not have a statistically significant effect on the incidence of chronic kidney failure in patients at the internist polyclinic of RST DD Hospital with a p-value of 0.135.

ADPKD (Autosomal Dominant Polycystic Kidney Disease) is the main cause of endstage renal failure. In Germany, there are about 32\% of patients with ADPKD undergo therapy in the form of hemodialysis, peritoneal dialysis, hemofiltration, hemodiafiltration, and kidney transplantation. As many as $75 \%$ of patients aged 70 years who suffer from ADPKD have kidney failure. A Canadian study reported that $25 \%$ of patients with ADPKD had a renal failure at the age of 47 years, $50 \%$ at the age of 59 years, and $75 \%$ at the age of 70 years. Meanwhile, another study conducted in France stated that $22 \%$ of patients with ADPKD had kidney failure at the age of 50 years, $42 \%$ at the age of 58 years, and $72 \%$ at the age of 73 years. ${ }^{12}$

Kidney polycystic disease is a genetic disease that is passed down from parents to their children. Polycystic kidney is characterized by the growth of cysts in the kidneys so that the size of the kidneys becomes larger than normal and the tissue in the kidneys is damaged. This condition causes chronic kidney failure. Generally, patients with new ADPKD will experience symptoms in the form of pain in the waist and experience hematuria at the age of 30-50 years. ${ }^{13}$

Polycystic kidney disease is an autosomal hereditary disorder that can affect adults as well as children. Polycystic kidney disease is divided into two, namely; Autosomal Recessive Polycystic Kidney which is usually caused by mutations in an as yet unidentified gene on chromosome 6p; and Autosomal Dominant Polycystic Kidney which is caused by a blind channel between the glomerulus and the tubule so that the fluid in the kidney cannot flow properly. ${ }^{14}$

The author argues that over time the cysts in the kidneys will get bigger, then it will damage the tissues in the kidney organs and lead to kidney failure. The growth of this cyst does not occur in a short time, it will even cause symptoms at the age of 30-50 years. Kidney cyst disease also cannot be prevented considering that kidney cysts are a genetic disease, but we can make efforts to reduce the progression of kidney damage so that it does not become chronic kidney failure.

Based on the results of the study, it showed that there was a statistically significant effect between a history of obstructive nephropathy and the incidence of chronic kidney failure 
in patients at the polyclinic of RST DD Hospital with a p-value of 0.018 with an OR of 0.205 , meaning that people who have a history of obstructive nephropathy have a risk of 0.205 times for experienced chronic renal failure when compared with people who did not have a history of obstructive nephropathy. This is in line with the results of a study conducted by Adhiatma, et al (2014), in his research stating that patients with obstructive nephropathy have a 3.7 times risk of experiencing chronic kidney failure. Then research conducted by Widyantara (2016) also stated that obstructive nephropathy has a relationship with the incidence of chronic kidney failure, with a risk of 3.6 times greater than patients without obstructive nephropathy.

Obstructive nephropathy usually occurs in patients who have a history of obstructive urinary tract lithiasis, vesicourethral reflux $\mathrm{BPH}$, bladder cancer, prostate cancer, or cervical cancer. Obstructive nephropathy is characterized by recurrent urinary tract infections, hypertension, and hydronephrosis. ${ }^{15}$

Renal or urethral scarring, neoplasms, stones, enlargement of the prostate gland, congenital abnormalities in the bladder neck and urethra, and narrowing of the urethra can cause obstruction. Obstruction of the urinary tract can cause fluid in the kidneys to accumulate in the kidneys and can further cause tissue shrinkage in the renal parenchyma which leads to chronic kidney failure. ${ }^{16}$

Blockage in the urinary tract that causes intrarenal pressure and is accompanied by recurrent urinary tract infections is the main factor causing damage to parenchyma tissue and nephrons in the kidneys, this condition can then progress to chronic kidney failure. Obstructive nephropathy patients who have a history of comorbidities such as diabetes mellitus, hypertension, and recurrent urinary tract infections have a greater risk of developing chronic kidney failure. ${ }^{17}$

Based on the results of research that has been done by the author and also based on the theory that has been described. The author believes that many things can cause obstructive nephropathies, such as the use of antibiotics, analgesics, and other drugs that are toxic to the kidneys for a long time, then blockage either due to stones or enlarged prostate gland, and a history of chronic disease. previous. So, it can be concluded that it takes a long journey before a person suffers from chronic kidney failure, meaning that although obstructive nephropathy influences the incidence of chronic kidney failure if the condition is found as early as possible and treated appropriately, this condition can get better.

\section{CONCLUSION AND SUGGESTION}


Based on the results of the analysis that has been carried out, it is stated that there is an influence of a history of diabetes mellitus, hypertension, and obstructive nephropathy on the incidence of chronic kidney failure in internist polyclinic patients at the Rumah Sehat Terpadu Dompet Dhuafa Hospital in 2021.

\section{REFERENCES}

1. Kementerian Kesehatan Republik Indonesia. 2018. Laporan Riset Kesehatan Dasar 2018. Jakarta.

2. Harmilah. 2020. Asuhan Keperawatan Gagal Ginjal Kronis. In: Asuhan Keperawatan Pada Pasien Dengan Gangguan Sistem Perkemihan. Yogyakarta: Pustaka Baru Press.

3. Choncol M, Chan L. 2018. Chronic Kidney Disease: Manifestations and Pathogenesis. In: Renal and Electrolyte Disorders. Colorado: Wolters Kluwer. 8 th edn. pp. $404-410$.

4. Langi FLFG, Ratag BT, Baroleh MJ. 2019. Faktor- Faktor Yang Berhubungan Dengan Penyakit Ginjal Kronis Pada Pasien Di Instalasi Rawat Jalan RSU Pancaran Kasih Manado. Fakultas Kesehat Masyarakat Universitas Sam Ratulangi Manado.

5. Ipo A, Aryani T, Suri M.2016. Hubungan Jenis Kelamin Dan Frekuensi Hemodialisa Dengan Kualitas Hidup Pasien Gagal Ginjal Kronik Yang Menjalani Hemodialisa Di Rumah Sakit Umum Daerah Raden Mattaher Jambi. Jurnal Akademi Baiturrahim Jambi.

6. Tandra H. 2018. Panduan Lengkap Mengenal dan Mengatasi Diabetes. Jakarta: Gramedia Pustaka Utama. edk 2. hh. 86-95.

7. Donelly R, Bilous R. Buku Pegangan Diabetes. Jakarta: Bumi Medika. edk 4. hh.130138.

8. Dunkler D, Kohl M, Heinze G, Teo KK, Rosengren A, Pogue J, et al. 2015. Modifiable Lifestyle and Social Factors Affect Chronic Kidney Disease in High-risk Individuals with Type 2 Diabetes Mellitus. Kidney Int. 87(4):784-791.

9. Pongsibidang GS. 2016. Risiko Hipertensi, Diabetes, dan Konsumsi Herbal Pada Kejadian Gagal Ginjal Kronik di RSUP dr. Wahidin Sudirohusodo Makassar. Jurnal Wiyata. 3(2):162-7.

10. Halid K, Soemantri $\quad$ D. 2015. Hipertensi dan Penyakit Ginjal Kronis. In: Manajemen Komprehensif Hipertensi. Surabaya: Airlangga University Press. edk 1. hh. 132.

11. Andriyani. 2020. Determinan Kejadian Hipertensi Lansia di RSU Kota Tangerang Selatan Tahun 2019. Universitas Respati Indonesia. 
E-ISSN: 2808-5361 http://e-journal.fkmumj.ac.id/
Proceeding The First

Muhammadiyah

Internasional- Public Health and Medicine Conference

12. Bergmann C, Guay- Woodford LM, Harris PC, Horie S, Peters DJM, Torres VE. 2018. Polycystic Kidney Disease. Nature Reviews Disease Primers, Nature Publishing Group. pp. 50.

13. American Kidney Fund.2020. Polycystic Kidney Disease (PKD) Symptoms, Treatments, \& Causes [Internet]. American Kidney Fund (AKF). Dilihat pada 28 Mei<https://www.kidneyfund.o rg/kidney-disease/other- kidney- conditions/polycystickidney-disease.html>

14. Afriani N, Widayati D.2017. Asuhan Keperawatan Pada Polycystic Renal Disease. In: Gangguan Pada Sistem Perkemihan \& Penatalaksanaan Keperawatan. Yogyakarta: Deepublish. hh. 144-148.

15. PERNEFRI.2018.Indonesian Renal Registry.11th Report Of Indonesian Renal Registry 2018. Indonesia Renal Registry. Jakarta.

16. Adhiatma AT, Wahab Z, Fajar I, Widyantara E. 2014. Analisis Faktor-Faktor yang Berhubungan dengan Kejadian Gagal Ginjal Kronik Pada Pasien Hemodialisis Di RSUD Tugurejo Semarang. Fakultas Kedokteran Universitas Muhammadiyah Semarang.

17. Wardani MAF.2014.Hubungan Batu Saluran Kemih Dengan Penyakit Ginjal Kronik di Rumah Sakit An Nur Yogyakarta Periode Tahun 2012 - 2013. Universitas Muhammadiyah Surakarta. 
Volume I Tahun 2021

November 2021
E-ISSN: 2808-5361

http://e-journal.fkmumj.ac.id/
Proceeding The First

Muhammadiyah

Internasional- Public Health and Medicine Conference 